\title{
Seafloor Change Around the Mississippi Barrier Islands, 1920 to 2016-The Influence of Storm Effects on Inlet and Island Morphodynamics
}

By James G. Flocks, Noreen A. Buster, and Owen T. Brenner

Open-File Report 2019-1140

U.S. Department of the Interior

U.S. Geological Survey 


\section{U.S. Department of the Interior \\ DAVID BERNHARDT, Secretary}

\section{U.S. Geological Survey \\ James F. Reilly, Director}

U.S. Geological Survey, Reston, Virginia: 2020

For more information on the USGS-the Federal source for science about the Earth, its natural and living resources, natural hazards, and the environment-visit https://www.usgs.gov/ or call 1-888-ASK-USGS (1-888-275-8747).

For an overview of USGS information products, including maps, imagery, and publications, visit https://store.usgs.gov/.

Any use of trade, firm, or product names is for descriptive purposes only and does not imply endorsement by the U.S. Government.

Although this information product, for the most part, is in the public domain, it also may contain copyrighted materials as noted in the text. Permission to reproduce copyrighted items must be secured from the copyright owner.

Suggested citation:

Flocks, J.G., Buster, N.A., and Brenner, O.T., 2020, Seafloor change around the Mississippi barrier islands, 1920 to 2016-The influence of storm effects on inlet and island morphodynamics: U.S. Geological Survey Open-File Report 2019-1140, 23 p., https://doi.org/10.3133/ofr20191140.

ISSN 2331-1258 (online) 


\section{Acknowledgments}

This study was funded in part by the U.S. Army Corps of Engineers Mississippi Coastal Improvement Project and builds upon the recent U.S Geological Survey reports of DeWitt and others (2018) and Buster and others (2017). The authors would like to thank Karen Morgan, David Thompson, and Stokely Klasovsky for their review of this report. 


\section{Contents}

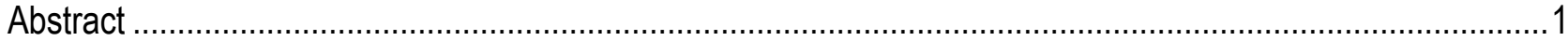

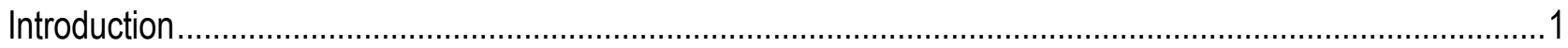

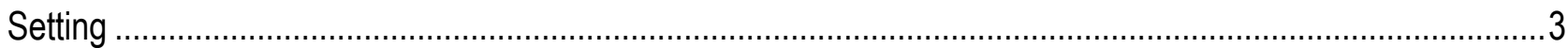



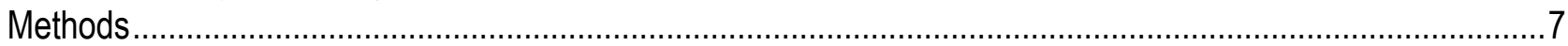



Long-term Change (1920-2016) …………................................................................................ 11

Recent Change (2009-2016) .....................................................................................................

Elevation Profiles ...................................................................................................................... 14

Temporal and Spatial Sedimentation Patterns.................................................................................. 18

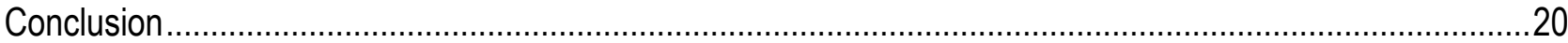



\section{Figures}

1. Maps showing regional locations, the Mississippi Barrier Islands, and the various features discussed in this report....................................................................................................................2

2. Satellite images showing the pre-storm and post-storm effects of Hurricane Katrina on the island morphology of West and East Ship islands .............................................................................

3. Digital elevation models generated from the 1920s, 2009, and 2016 bathymetric data........................

4. Trackline maps showing survey extent from 1916-1920; 2008-2009; and 2016 ..............................8

5. Maps showing elevation change determined by calculating the difference between DEMs for an approximate 96-year period from 1920s to 2016; an approximate 7-year period from 2009 to 2016; and an approximate 89-year period from 1920 to 2009 ..............................................................10

6. Stacked elevation profiles from the three time periods along the gulf and sound sides of West Ship and East Ship islands, and through Camille Cut .....................................................................15

7. Stacked elevation profiles from the three time periods longitudinally across Little Dog Keys and Dog Keys passes, Little Dog Keys Inlet, and Dog Keys Pass

8. Stacked elevation profiles from the three time periods along Horn Island, longitudinally across Horn Island Pass, and onshore-offshore through the Horn Island Pass

9. Bar graph showing sediment volumetric change per unit area of each reference subsection for the long and short time periods; and rate of change for each reference subsection during the same time periods.

\section{Tables}

1. Tropical storms passing within 185 kilometers of Ship Island since 1920

2. Accretion and erosion volumes, net change, and rate of change for the reference subsections that represent key morphologic features 


\section{Conversion Factors}

International System of Units to U.S. customary units

\begin{tabular}{|c|c|c|}
\hline Multiply & By & To obtain \\
\hline \multicolumn{3}{|c|}{ Length } \\
\hline centimeter $(\mathrm{cm})$ & 0.3937 & inch (in.) \\
\hline meter $(\mathrm{m})$ & 3.281 & foot $(\mathrm{ft})$ \\
\hline millimeter $(\mathrm{mm})$ & 0.03937 & inch (in.) \\
\hline kilometer $(\mathrm{km})$ & 0.6214 & mile (mi) \\
\hline kilometer (km) & 0.5400 & mile, nautical (nmi) \\
\hline meter $(\mathrm{m})$ & 1.094 & yard $(y d)$ \\
\hline
\end{tabular}

\section{Datum}

Vertical coordinate information is referenced to the North American Vertical Datum of 1988 (NAVD 88, GEOID12A), and converted to mean lower low water (MLLW) for analysis purposes. Units of all vertical measurements are in meters. Horizontal coordinate information is referenced in the geographic coordinates World Geodetic System of 1984 (WGS 84); however, data were projected into Universal Transverse Mercator (UTM) coordinate system for analysis purposes.

\section{Abbreviations}

$\begin{array}{ll}\text { DEM } & \text { digital elevation models } \\ \text { EAARL } & \text { Experimental Advanced Airborne Research Lidar } \\ \text { Geoid12B } & \text { vertical datum NAVD88 } \\ \text { GIS } & \text { geographic information system } \\ \text { GMT } & \text { Generic Mapping Tools } \\ \text { GOM } & \text { Gulf of Mexico } \\ \text { GUIS } & \text { Gulf Islands National Seashore } \\ \text { H-sheets } & \text { hydrographic sheets } \\ \text { ka } & \text { kilo annum, thousand calendar years ago } \\ \text { kts } & \text { knots } \\ \text { m } 3 & \text { cubic meters } \\ \text { mb } & \text { millibars } \\ \text { MHW } & \text { mean high water } \\ \text { MLLW } & \text { mean lower low water } \\ \text { mm } & \text { millimeters } \\ \text { MS } & \text { Mississippi Sound } \\ \text { MsCIP } & \text { Mississippi Coastal Improvement Project } \\ \text { NAD83 } & \text { North American 1983 datum } \\ \text { NAVD88 } & \text { North American Vertical Datum of 1988 } \\ \text { nmi } & \text { nautical mile } \\ \text { NOAA } & \text { National Oceanic and Atmospheric Administration } \\ \text { NPS } & \text { National Park Service } \\ \text { SPCMSC } & \text { St. Petersburg Coastal and Marine Science Center } \\ \text { T } & \text { transects } \\ \text { USACE } & \text { U.S. Army Corps of Engineers } \\ \text { USGS } & \text { U.S. Geological Survey } \\ \text { UTM } & \text { Universal Transverse Mercator } \\ \text { v.e. } & \text { vertical exaggeration } \\ \text { WGS84 } & \text { World Geodetic System of 1984 } \\ \text { WHCMSC } & \text { Woods Hole Coastal and Marine Science Center } \\ \text { yr } & \text { year } \\ & \end{array}$




\title{
Seafloor Change Around the Mississippi Barrier Islands, 1920 to 2016-The Influence of Storm Effects on Inlet and Island Morphodynamics
}

\author{
By James G. Flocks, Noreen A. Buster, and Owen T. Brenner
}

\begin{abstract}
The Mississippi Barrier Islands in the northern Gulf of Mexico experienced high rates of spatial change over recorded history. Wave-induced sediment transport induced island migration, landward retreat, and inlet evolution. These processes can be measured using repeat bathymetric surveys to analyze elevation change over time. This study analyzes digital elevation models created from three time periods where bathymetric data have been collected: the 1920s, 2009, and 2016. The models are compared to assess volumetric change between surveys and characterize morphologic responses to natural and human-influenced processes. Although all the islands within the study area experienced a loss of area over the period of study, the nearshore and tidal inlets experience both accretion and erosion that vary spatially and temporally. Major morphologic changes include westward island migration, expanding ebb-tidal deltas, and changes in inlet dimensions. This study is a collaboration between the U.S. Geological Survey, the U.S. Army Corps of Engineers, and the National Park Service to establish baseline physical and pre-restoration morphologic conditions preceding a major restoration of the islands as part of the Mississippi Coastal Improvement Project.
\end{abstract}

\section{Introduction}

The barrier island platform located offshore of the State of Mississippi in the Gulf of Mexico supports five islands: Cat, West Ship, East Ship, Horn, and Petite Bois (fig. 1), although the island system has a history of ephemeral islands and island segmentation (Morton, 2008). The islands are about 11-14 kilometers (km) seaward of the mainland and separate the Gulf of Mexico from Mississippi Sound. The islands and surrounding waters comprise the Gulf Islands National Seashore (GUIS) and contain a variety of environments including barrier dunes, wetlands, sandy beaches, and tidal inlets that provide critical habitat for threatened and endangered species, protect the mainland from storm surge and waves, and maintain a salinity gradient and estuarine ecosystem within Mississippi Sound. The submerged regions of the platform are highly variable in morphology and are sedimentologically dynamic. The morphologic features include wide tidal inlets that support broad ebb-tidal deltas, westward-prograding island spits, and an extensive range of shoreface gradients.

Morphodynamic processes on the island platform are influenced by a predominantly east to west sediment transport system driven by a regional wave direction from the southeast (Byrnes and others, 2013; Flocks and others, 2015). The westward littoral drift results in the persistent erosion of sediment from the updrift side of the islands and deposition on the downdrift side, while sediment migrates into and is sequestered as ebb-tidal deltas within the inlets. This long-term trend of island migration and inlet evolution is punctuated by drastic changes in island morphology during intense storms. Storm frequency occurs in multidecadal cycles (Morton, 2008), and hurricanes over the past century forced island overwash, retreat, and breaching (Otvos and Carter, 2013). 


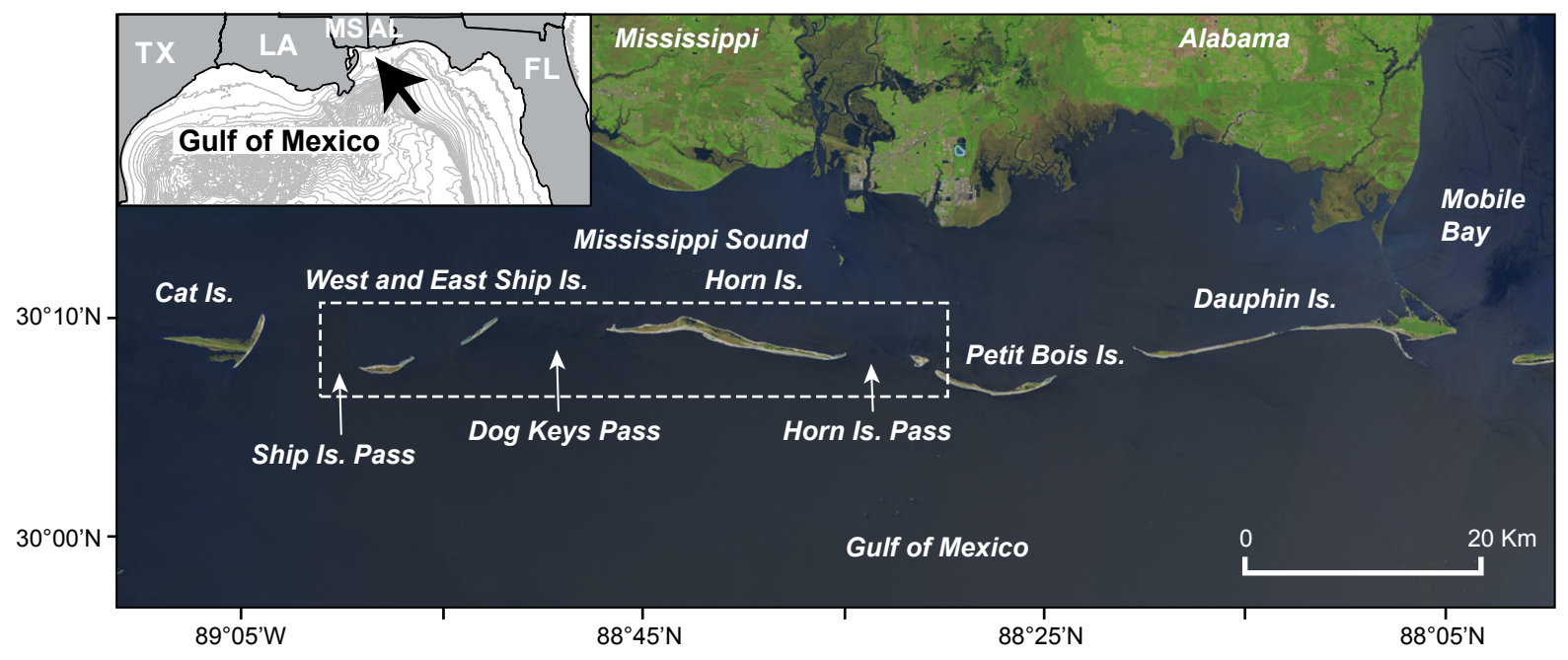

Figure 1. Maps showing regional locations, the Mississippi Barrier islands (inset), and the various features discussed in this report. The area outlined by the dashed polygon is the study area. The background satellite image is from 2014 U.S. Geological Survey Landsat 8.

Over the past century, the GUIS islands experienced a significant loss of land area. An analysis of shoreline change since the 1800s (Morton, 2007, 2008) defined three morphodynamic processes that led to land loss: (1) diminished sand-transfer down-drift that led to higher net erosion rates, (2) island narrowing through island erosion on both the gulf and sound sides, and (3) island segmentation caused by storms. These processes led to a 24-64 percent loss in island area during this time. The predominant factor-reduced sediment supply-results from sand sequestration at the expanding ebb-tidal deltas and, to a lesser extent, the removal of sediments through the maintenance dredging of two shipping channels that cross the island platform (Morton, 2007, 2008; Buster and Morton, 2011; Byrnes and others, 2013). Offshore, shoals that may have provided sediments to the island platform in the past continued to submerge through late-Holocene sea-level rise and are no longer active contributors to the system (Flocks and others, 2015).

In 2005, Hurricane Katrina inundated the islands with a storm surge of 8 meters (m) (Fritz and others, 2007). The effects of storm surge and waves widened the breach between East and West Ship Islands (fig. 2), reduced dune elevations, and eroded shorelines throughout the GUIS. After Katrina, the U.S. Geological Survey (USGS), in collaboration with the National Park Service (NPS), started to regionally characterize the geology and morphology of the barrier island system, including an assessment of shoreline and bathymetric change. These efforts formed the basis for a collaboration with the U.S. Army Corps of Engineers (USACE).

The USACE was tasked, through the USACE Mississippi Coastal Improvement Project (MsCIP), with the restoration of clearly defined portions of coastal Mississippi and the GUIS. Within the GUIS, the USACE restoration efforts include closing the breach between East and West Ship Islands and placing sand within the littoral zone on the updrift side of East Ship Island. The expectation is that sediment transport, through normal wave action, will establish equilibrium within the shoreface system, thereby fortifying the island platform seaward of the restored island.

Monitoring bathymetric change, over historical time scales and since Hurricane Katrina, is critical in understanding the evolution and resilience of the island system. Repeated subaqueous elevation surveys provide information about depositional and erosional trends and events. Performing 

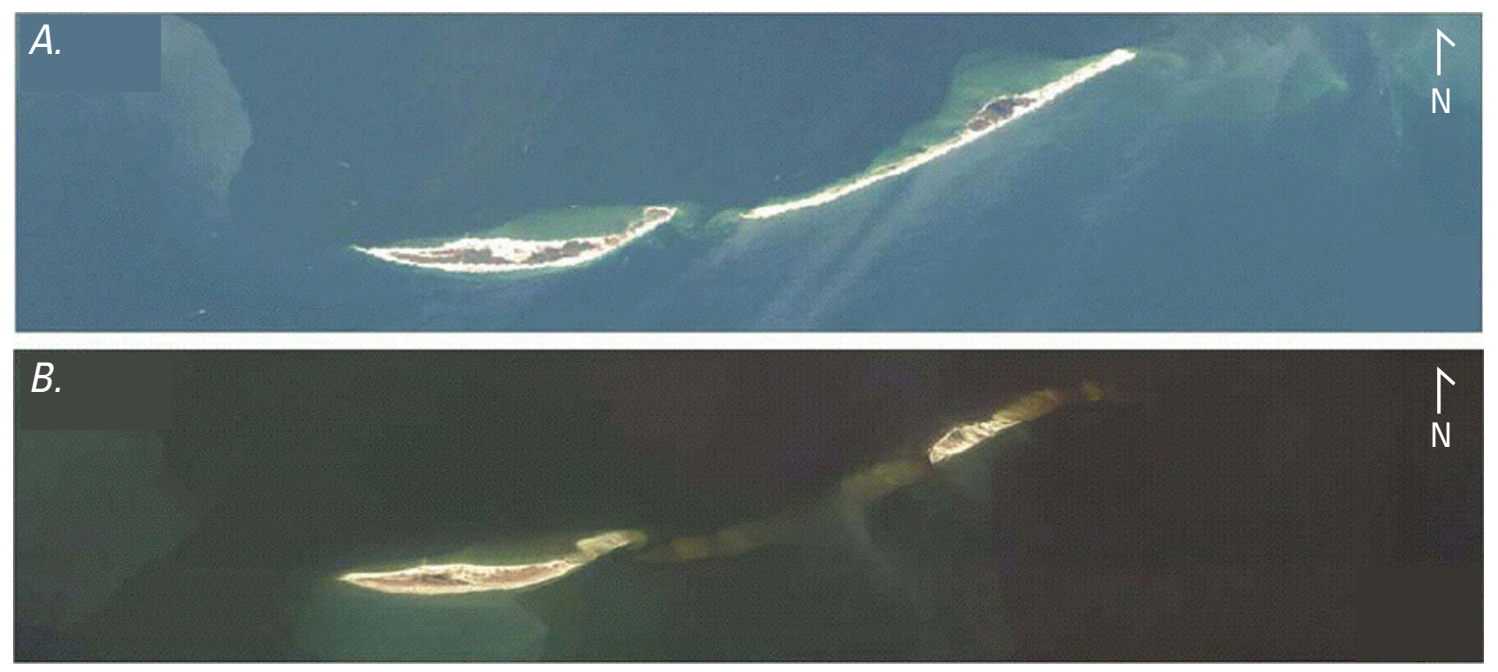

Figure 2. Satellite images showing the $(A)$ pre-storm (1997) and (B) post-storm (2005) effects of Hurricane Katrina (2005) on the island morphology of West and East Ship Islands. East Ship Island was inundated, and the breach between the islands (Camille Cut) widened significantly. Imagery modified from Flocks and others (2009; https://archive. usgs.gov/archive/sites/soundwaves.usgs.gov/2009/03/index.html).

a bathymetric assessment prior to the implementation of an island restoration project is a necessary step in defining base-level conditions and establishing a metric that can be used to monitor island restoration over time and gauge success.

In July 2016, the USGS - in collaboration with the USACE and NPS, with funding provided by the MsCIP project - performed a bathymetric survey around Horn Island, East and West Ship islands, and the adjoining inlets. The results of the survey are reported in DeWitt and others (2018) and Buster and others (2017), which contain the digital elevation models (DEM) derived from the processed data that are shown in figure 3 of this report. This study is a continuation of ongoing bathymetric monitoring within the GUIS to monitor restoration efforts, with the intent to update long-term change analysis (Buster and Morton, 2011), measure recent change, and establish baselevel conditions prior to restoration activities.

This report compares the DEM generated by this study with the DEM from the last bathymetric survey acquired in 2008 and 2009 (herein referred to as the 2009 time period), and to a historically derived DEM created using data from a bathymetric survey conducted in the 1920s (fig. 3). These comparisons help quantify short-term and long-term changes across the island platform. Island platform recovery following Hurricane Katrina represents a time period of no direct storm effects. During this quiescent period, the elevation changes reflect fair-weather nearshore processes and sediment dynamics across the platform, as other drivers of elevation change (tectonic adjustment, Holocene subsidence, and eustatic sea-level rise) are negligible (Flocks and others, 2011).

\section{Setting}

The present-day Mississippi barrier islands follow an evolutionary trend of islands that extended from the entrance of Mobile Bay, Alabama, to present-day New Orleans, Louisiana (fig. 1). This older island system formed about 4-5.5 thousand calendar years ago (ka) as the rising sea transgressed the area and littoral drift aggradation, driven by a prevalent southeast wave 

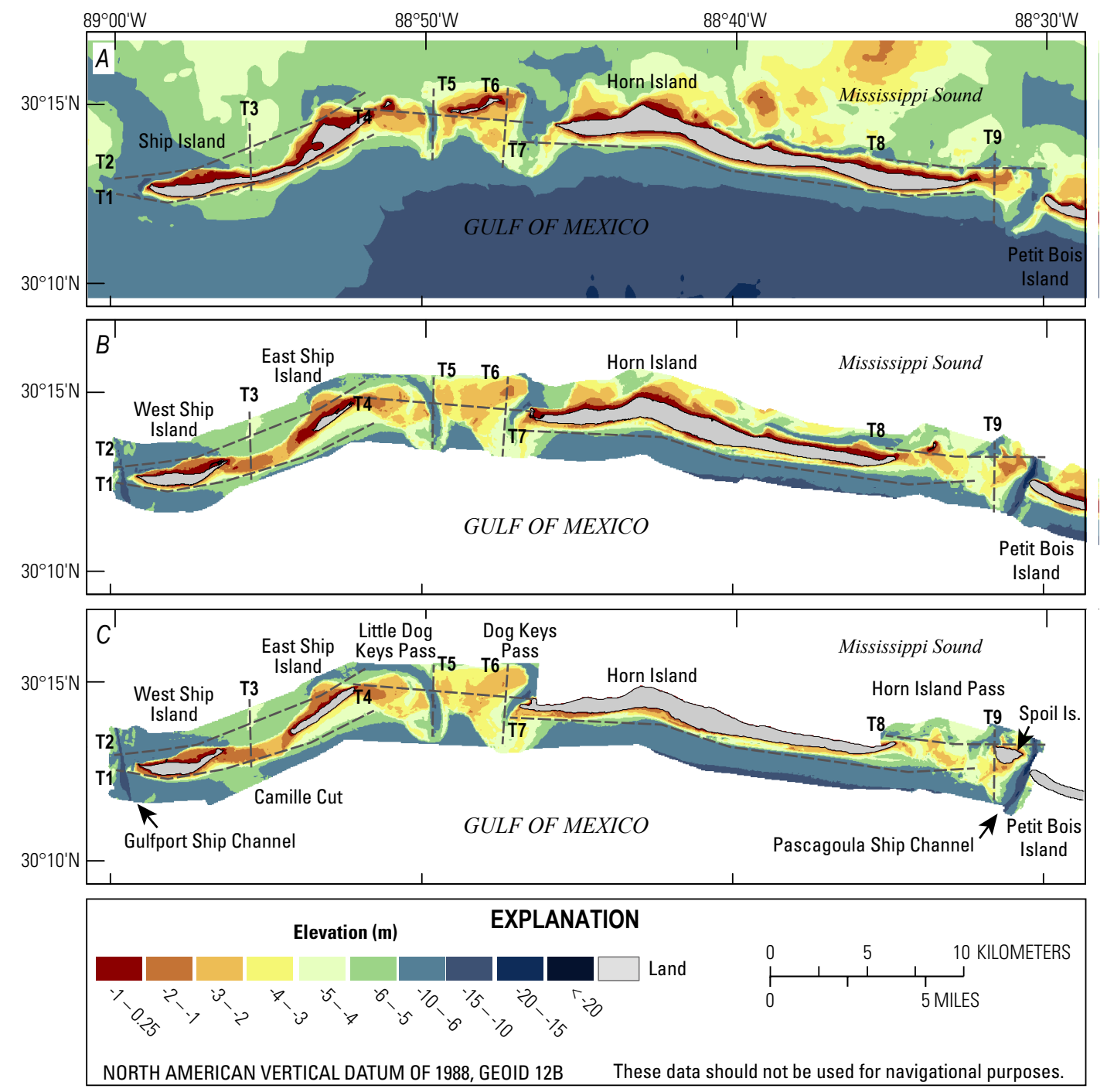

Figure 3. Digital elevation models (DEM) generated from $(A)$ the 1920s $(B), 2009$, and $(C) 2016$ bathymetric data. The DEMs are available at Buster and others (2017). Overlain on the DEMs are transect locations (T1-T9) used to show elevation changes over time (figs. 6-8). Elevation shown in meters (m).

climate, reworked sand from the former Pleistocene platform into shoals (Otvos, 1981; Otvos and Carter, 2013; Miselis and others, 2014). Historically, sediment supply from offshore, from former Mobile River deposits, and from the Mobile Bay ebb-tidal delta to the east, contributed to the extensive ridge-plain development evident today on Horn and Cat Islands. From 4 ka to 2 ka, the advancement from the west of the St. Bernard delta complex of the Mississippi River altered sedimentation patterns across the Mississippi-Alabama inner shelf and blanketed the area with prodeltaic mud deposits (Otvos and Giardino, 2004; Twichell and others, 2011). Most recently, the sediment supply from the east has significantly diminished, and without this supply, the islands entered a stage of deterioration.

This report focuses on Horn, East Ship, and West Ship islands. Dog Keys Pass separates Horn Island from East Ship Island and contains two natural inlets - the main Dog Keys Pass and the Little Dog Keys Pass to the west—both of which contain large ebb-tidal deltas (fig. 3). On the 
eastern end of the study area, Horn Island Pass separates Horn Island from Petit Bois Island to the east. The inlet supports a well-developed ebb-tidal delta and has an actively maintained shipping channel. Ship Island Pass, to the west of West Ship Island, also includes an actively maintained shipping channel that, in the early 1990s, was realigned farther west as West Ship Island migrated into the former channel. The tidal flow through the pass is relatively low due to its width $(8 \mathrm{~km})$, and the pass receives little sediment via littoral transport from West Ship Island (Byrnes and others, 2013). As a result, no ebb-tidal delta has developed in Ship Island Pass as in the other inlets.

Mississippi Sound is a diurnal, microtidal estuary with a tidal range of $0.5 \mathrm{~m}$. An analysis of wave data from a sea buoy located $85-\mathrm{km}$ east-southeast of the study area (National Oceanic and Atmospheric Administration [NOAA] sea buoy 42012) shows a mean south-southeast wave vector, ranging from 110 to 180 degrees (Flocks and others, 2015), which produces a net westward longshore sediment transport at the islands. Mean wave height at sea buoy 42012 is $0.87 \mathrm{~m}$, but wave heights at the islands are lower; models of breaking wave heights on the shorelines suggest a range of $0.3-0.6 \mathrm{~m}$ (Byrnes and others, 2013).

\section{Storm History and Navigation Channel Maintenance}

Since 1923, a total of 27 storms with the intensity of a tropical storm, or greater, passed within $185 \mathrm{~km}$ (100 nautical miles [nmi]) of the Mississippi barrier islands (table 1). Besides strength, there are many storm characteristics that can affect island and seafloor change, including the direction of approach, the duration, and the associated water surge. Of these 27 storms, 13 had a combination of features that were reported to have caused significant erosion of the islands (highlighted in table 1). The breach of Ship Island, forming West and East Ship Islands, provides an indicator of the significant effects that can result from a storm (fig. 2).

Commonly known as Camille Cut, this breach opened and closed numerous times over recorded history, with an early breach event depicted in a nautical chart from 1853 (Morton, 2008) and again in 1947, when an unnamed hurricane caused a 4-m storm surge, breaching Ship Island. Over time, the breach closed, but it was reopened by Hurricane Ethel in 1960 and was significantly widened by its namesake storm, Camille, in 1969. The center of Hurricane Camille passed within $60 \mathrm{~km}$ of Ship Island as a Category 5 storm, inundating the island with a 4.7-m surge (Morton, 2007 and 2008).

In 1985, the eye of Hurricane Elena passed within $6 \mathrm{~km}$ of Ship Island, producing a 1.25-m surge and removing any recovery at the breach. Twenty years later, Hurricane Katrina devastated the GUIS and the mainland with an 8-m surge. The storm widened the breach and nearly wiped out East Ship Island. (fig. 2). The northern Gulf of Mexico experienced a relatively low frequency of storm impacts in the decade following Katrina, with only two tropical-strength storms passing within $100 \mathrm{~km}$ of the GUIS during the study period (table 1). On October 8, 2017, Tropical Storm Nate passed over the GUIS as a weakening Category 1 storm. Post-storm aerial photography shows shoreline erosion and overwash on the islands (https://coastal.er.usgs.gov/hurricanes/nate/ photo-comparisons/index.php). However, this storm occurred after the 2016 bathymetry survey and is not part of this report.

The Horn Island Pass Ship Channel (also known as the Pascagoula and Pascagoula Bar Ship Channel, fig. 3) is a dredged channel that has been maintained through Horn Island Pass since the early 1900s. Throughout the study period, the channel was periodically deepened, widened, and lengthened (Byrnes and others, 2012). The channel acts as a sediment sink for sand migrating west from the ebb-tidal delta located at Petit Bois Pass, and some of the sediment dredged from the 
Table 1. Tropical storms passing within 185 kilometers $(\mathrm{km})$ (100 nautical miles [nmi]) of Ship Island since 1920. Thirteen storms, highlighted in grey, had a combination of features that caused significant erosion of the islands. Storm data were extracted from the National Oceanic and Atmospheric Administration Historical Hurricane Track Tools v. 4.0 (https://coast.noaa.gov/hurricanes/).

[km, kilometers; mb, millibars; kts, knots; m, meters; --, no data]

\begin{tabular}{|c|c|c|c|c|c|c|c|}
\hline Storm name & Year & $\begin{array}{c}\text { Closest } \\
\text { distance } \\
(\mathrm{km})\end{array}$ & Category & $\begin{array}{c}\text { Central } \\
\text { pressure } \\
(\mathrm{mb})\end{array}$ & $\begin{array}{c}\text { Central } \\
\text { wind speed } \\
\text { (kts) }\end{array}$ & $\begin{array}{l}\text { Wind gust } \\
\text { at GUIS } \\
\text { (kts) }\end{array}$ & $\begin{array}{c}\text { Surge at GUIS } \\
\text { (mainland }) \\
(\mathrm{m})\end{array}$ \\
\hline Ida & Nov 2009 & 57 & TS & 998 & 50 & 225 & $(2.0)$ \\
\hline Cindy & Jul 2005 & 54 & TS & 995 & 45 & -- & $(2.2)$ \\
\hline Katrina & Sep 2005 & 65 & H3 & 928 & 105 & ${ }^{3} 168$ & ${ }^{3} 8(8)$ \\
\hline Ivan & Sep 2004 & 102 & H3 & 943 & 105 & ${ }^{3} 65$ & ${ }^{3} 1.5(4)$ \\
\hline Hanna & Sep 2002 & 28 & TS & 1002 & 50 & -- & (1.5) \\
\hline Georges & Sep 1998 & 6 & $\mathrm{H} 2$ & 964 & 90 & 106 & ${ }^{3} 2.2(3.7)$ \\
\hline Danny & Jul 1997 & 59 & H1 & 986 & 70 & ${ }^{2} 46$ & -- \\
\hline Opal & Sep 1995 & 161 & $\mathrm{H} 3$ & 940 & 105 & -- & -- \\
\hline Florence & Sep 1988 & 93 & TS & 988 & 60 & -- & (2.3) \\
\hline Elena & Aug 1985 & 5 & $\mathrm{H} 3$ & 959 & 100 & ${ }^{3} 107$ & ${ }^{3} 1.2$ \\
\hline Juan & Oct 1985 & 73 & TS & 980 & 60 & 54 & $(0.6)$ \\
\hline Frederic & Aug 1979 & 70 & $\mathrm{H} 4$ & 946 & 115 & ${ }^{3} 124$ & ${ }^{3} 2.4(4.7)$ \\
\hline Camille & Aug 1969 & 61 & H5 & 908 & 150 & ${ }^{3} 162$ & ${ }^{3} 4.7(7.5)$ \\
\hline Ethel & Sep 1960 & 4 & H1 & 982 & 70 & 140 & ${ }^{3} 1.2(2.1)$ \\
\hline Irene & Oct 1959 & 123 & TS & 1000 & 40 & -- & -- \\
\hline Brenda & Aug 1955 & 68 & TS & -- & 55 & -- & (1.8) \\
\hline Unnamed 1955 & Aug 1955 & 35 & TS & -- & 45 & -- & $(1.1)$ \\
\hline Flossy & Sep 1955 & 85 & $\mathrm{H} 1$ & 975 & 80 & ${ }^{4} 52$ & ${ }^{4} 1.1(4.0)$ \\
\hline Baker & Aug 1950 & 87 & H1 & 979 & 75 & -- & -- \\
\hline Unnamed 1948 & Sep 1948 & 92 & TS & 1086 & 60 & -- & ${ }^{3} 1.8(1.8)$ \\
\hline Unnamed 1947 & Sep 1947 & 89 & $\mathrm{H} 2$ & 966 & 95 & ${ }^{3} 81$ & ${ }^{3} 3.9(4.6)$ \\
\hline Unnamed 1947 & Sep 1947 & 79 & TS & -- & 45 & -- & -- \\
\hline Unnamed 1944 & Sep 1944 & 37 & TS & -- & 55 & -- & -- \\
\hline Unnamed 1937 & Sep 1937 & 120 & TS & -- & 40 & -- & -- \\
\hline Unnamed 1932 & Sep 1932 & 80 & H1 & 979 & 75 & -- & $(2.0)$ \\
\hline Unnamed 1923 & Oct 1923 & 8 & TS & -- & 50 & -- & $(2.4)$ \\
\hline Unnamed 1923 & Jun 1923 & 1 & TS & -- & 37 & -- & -- \\
\hline
\end{tabular}

${ }^{1}$ Southern Climate Impacts Planning Program (2018).

${ }^{2}$ National Oceanic and Atmospheric Administration (2018a).

${ }^{3}$ Morton (2008).

${ }^{4}$ National Oceanic and Atmospheric Administration (2018b). 
channel during maintenance is conveyed offshore and effectively removed from the littoral system. Byrnes and others (2012) estimate that dredging has removed a net volume of $4.8 \times 10^{6}$ cubic meters $\left(\mathrm{m}^{3}\right)$ from the system. This loss, along with the sediment-trapping efficiency of the channel and the inlet's ebb-tide delta, has reduced the sediment supply downstream to the study area.

The Gulfport Ship Channel west of Ship Island (fig. 3) was first excavated at the turn of the 20th century and maintained to a project depth of $8 \mathrm{~m}$ through maintenance dredging (Byrnes and others, 2012). Before excavation, there was a natural inlet at the same location, immediately adjacent to Ship Island (Buster and Morton, 2011), that early observers noted was maintained through "natural causes" (Byrnes and others, 2012). Persistent infilling of the ship channel through westward sediment transport from the GUIS platform resulted in a realignment of the channel to the west.

\section{Methods}

A bathymetric survey was performed in July 2016 (herein referred to as the 2016 time period) using a suite of acoustic systems and platforms (DeWitt and others, 2018). In summary, three shallow-draft vessels were equipped with single-beam and interferometric swath acoustic systems to measure water depths and acquired 667 line-km of single-beam bathymetric data and 844 line-km of swath bathymetric data, with water depths ranging from 0.6 to $17 \mathrm{~m}$. Positioning offsets were corrected using GPS base stations installed over geodetic benchmarks located on the islands. Variability in sound velocity due to density differences within the water column was corrected using periodic sound velocity profile measurements. Vessel heave, pitch, and roll were measured and compensated for using internal-motion reference systems on board the vessels. Figure 4 shows the extent of 2016 survey tracklines and, for comparison, the trackline data from the 1920s and 2009 surveys. Note that for volumes calculated for each subsection that includes the 1920s data, data coverage in the nearshore of West Ship, East Ship, and Horn islands may be skewed high or low, as the DEM was heavily interpreted in these areas.

The 2016 bathymetric data were collected and processed in the World Geodetic System 1984 (WGS84) datum with ellipsoid heights and then converted to the North American 1983 datum (NAD83) Universal Transverse Mercator (UTM) zone 16 and vertical datum NAVD88 (Geoid12B). Elevation measurements from the three vessels were merged to generate a DEM of the study area; data descriptions and availability can be found in DeWitt and others (2018) and Buster and others (2017). Island shorelines are assigned a value of $0.23 \mathrm{~m}$ : this value is considered the operational mean high water (MHW) for this area (Weber and others, 2005) and was assigned as an attribute of the shoreline polygons from 2015 USGS Landsat satellite imagery (Guy, 2015a, b). Note that this value may underestimate volume changes in areas where the island has been submerged since the 1920s, as island elevation may have been higher.

For use in monitoring seafloor change over time, additional historically derived (1920s) and recent (2008-09) DEMs were created for the legacy time periods (Buster and others, 2017). Datasets include soundings collected between 1916 and 1920 by the U.S. Coast and Geodetic Survey as hydrographic sheets (H-sheets; herein referred to as the 1920 time period). The 1916-17 island shoreline data were downloaded from the NOAA National Geodetic Survey (NGS) Shoreline Database (Buster and Morton, 2011). The USGS St. Petersburg Marine Science Center (USGS SPCMSC) and the USGS Woods Hole Coastal and Marine Science Center (USGS WHCMSC) collected the 2008-09 bathymetric soundings. A 2007 shoreline was extracted from USGS Experimental Advanced Airborne Research Lidar (EAARL) data (Buster and Morton, 2011). 


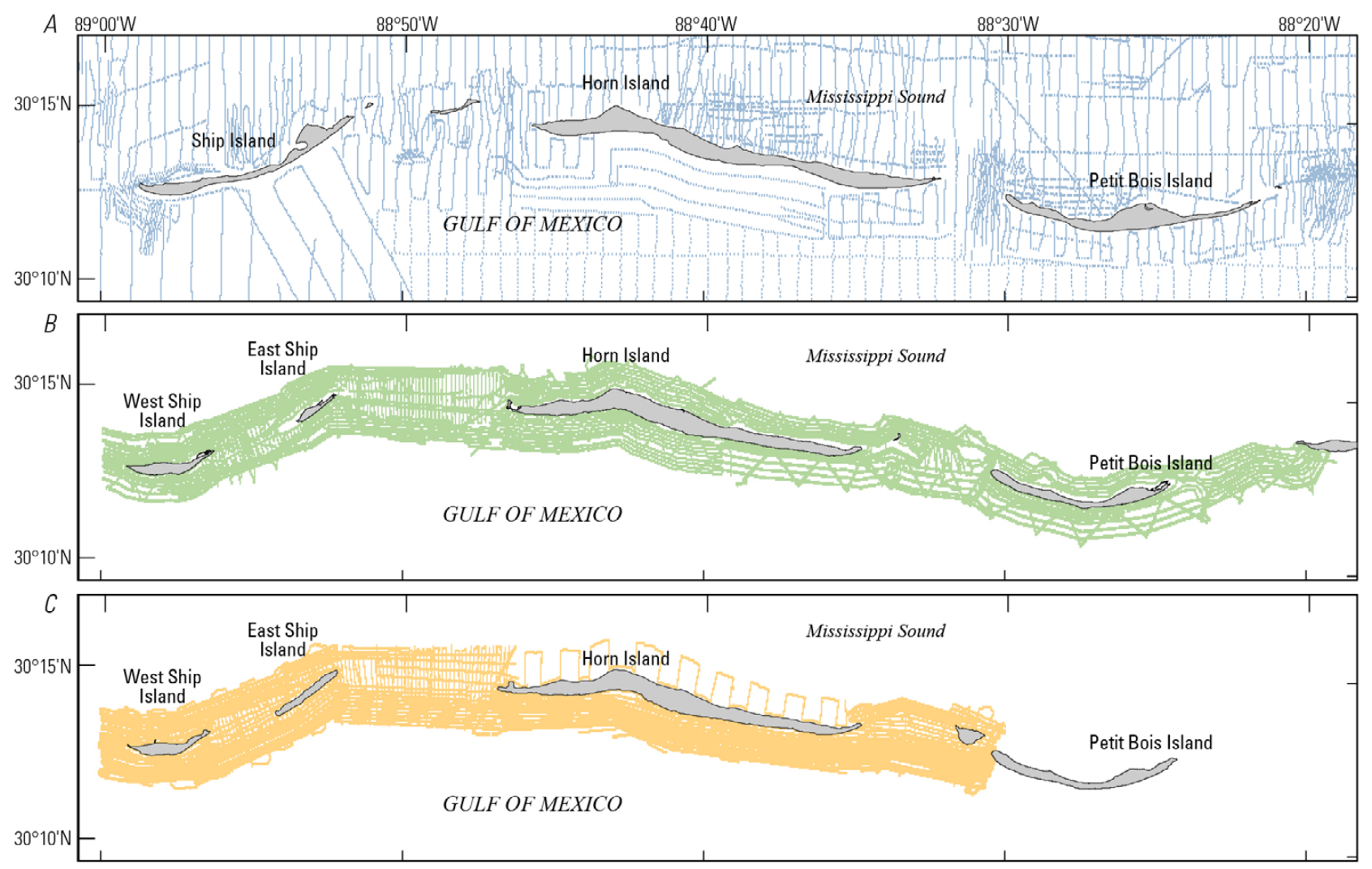

EXPLANATION

Land



Figure 4. Trackline maps showing survey extent of $(A), 1916-1920 ;(B), 2008-2009$; and $(C), 2016$. See Buster and Morton (2011) and Buster and others (2017) for details. For analysis, the digital elevation model (DEM) derived from the survey data was clipped to the area represented by the polygon (purple line).

For accurate comparisons with the 2016 bathymetric dataset, soundings from both the 1920 and 2009 time periods were adjusted for consistent horizontal and vertical reference datums (NAD83, NAVD88 geoid 12B) using NOAA's Vdatum software (https://vdatum.noaa.gov/; 2009 data were originally published in Dewitt and others, [2012]). Before the vertical transformations, updated water-level corrections were applied to the 1920 original sounding data from Buster and Morton (2011) using a value that accounts for the trend of sea-level increase from 2.1 millimeters per year (mm/yr) in 2008 to $2.31 \mathrm{~mm} / \mathrm{yr}$ in 2016, as reported by the NOAA tide gage (https:// tidesandcurrents.noaa.gov/map/index.html) at Pensacola, Florida (National Oceanic and Atmospheric Administration, 2018a). Linear regression was applied to the tide-gage data from Pensacola to obtain an averaged water-level correction offset of $0.17 \mathrm{~m}$ between the years 1916 and 1920 (Buster and others, 2017), compared to the previous adjustment of $0.16 \mathrm{~m}$ (Buster and Morton, 2011).

All DEMs were produced following the same methods within Esri ArcGIS by creating a triangulated irregular surface (TIN) from the bathymetry data points, a coincident shoreline file (using operational MHW $0.23 \mathrm{~m}$ for elevation), and a polygon of the respective survey extent. The final DEMs were created using the "TIN to raster" tool, with natural neighbors at the 50-m cell size. 
A 50-m snap raster file (Buster and others, 2017) was applied to all DEMs to ensure consistent cell center-locations for change analyses. The resulting DEMs are shown in figure 3 . The root mean square error for the grid, relative to the soundings across acquisition platforms, was $0.32 \mathrm{~m}$. The data, DEMs, and associated metadata are available in Buster and others (2017).

For data comparison among time periods, the DEMs from the legacy time periods were clipped to the extent of the 2016 survey (purple polygon in fig. 4). Once the three DEMs were sampled to the same geographic extents and vertical datum (NAVD88 geoid 12B), the bathymetric change between each period (2009-2016, 1920-2009, and 1920-2016) was computed using the raster calculator in ArcGIS. This calculation provides an isopach grid of erosion (negative values) and accretion (positive values). The greatest combined uncertainties of comparing grids were approximately $44 \mathrm{~cm}$, but to show uncertainty, isopach differences between $-0.25 \mathrm{~m}$ and $+0.25 \mathrm{~m}$ were considered within the error of analysis (white, no change) and change error was calculated within this interval.

To visualize relative elevation change between time periods, two-dimensional profiles across the DEMs, for each time period, were stacked. Nine transects (T1 through T9) were selected across areas that represent inlet and shoreface process regimes (see fig. 3 for transect locations). Transects were extracted from the DEMs using the transit plug-in included with the QGIS geographic information system (GIS) software (v. 2.18; https://www.qgis.org/) to generate the profiles. The transects were selected to follow the 1920 s point data, which have the lowest resolution of coverage, as closely as possible (fig. 4).

A volume-change analysis quantifying spatial and temporal change was performed using separate areas that were selected to represent tidal-inlet and shoreface subsections. These areas, referred to as reference subsections and shown as light-gray, dashed-line polygons in figure 5, are important geomorphic features used to compare relative change around the islands. The criteria for polygon selection included the following: restricting polygons to the sound side and gulf-side areas of the islands, keeping inlets as separate areas from the most recent (2015) lidar-derived shoreline locations, and excluding shipping channels from calculations. For subsections 1 and 2, 3 and 4, and 8 , the boundary between the gulf and sound polygons was drawn on the gulf side in front of the 2015 shoreline. The volumes for each subsection-polygon were calculated using the grdvolume function in the Generic Mapping Tools (GMT), which calculates area, volume, and volume per unit area within a DEM. The reference subsections (fig. 5) include: (1) West Ship Island to Mississippi Sound; (2) West Ship Island to the Gulf of Mexico; (3) East Ship Island to Mississippi Sound; (4) East Ship Island to the Gulf of Mexico; (5) Camille Cut; (6) Little Dog Keys Pass; (7) Dog Keys Pass; (8) Horn Island to the Gulf of Mexico, and (9) Horn Island Pass.

\section{Results and Discussion}

The DEMs from three time periods (1920, 2009, and 2016) show persistent morphologic features across the study area. Starting from the east, Horn Island Pass expanded in width over the past century (fig. 3), and a comparison of DEMs from the mid-1880s (Buster and Morton, 2011) to DEMs from the 1920s shows the development of a natural tidal inlet through the pass. Engineering logs from the late 1880s show that the pass appeared to be deepening from year to year through natural causes (Byrnes and others, 2012). The inlet deepening was augmented, beginning in 1897, by dredging to maintain the Pascagoula Bar Channel, which is clearly defined in the 1920 DEM. By the 1960s, sediment from the maintenance dredging of the ship channel was placed in an adjacent disposal area, 

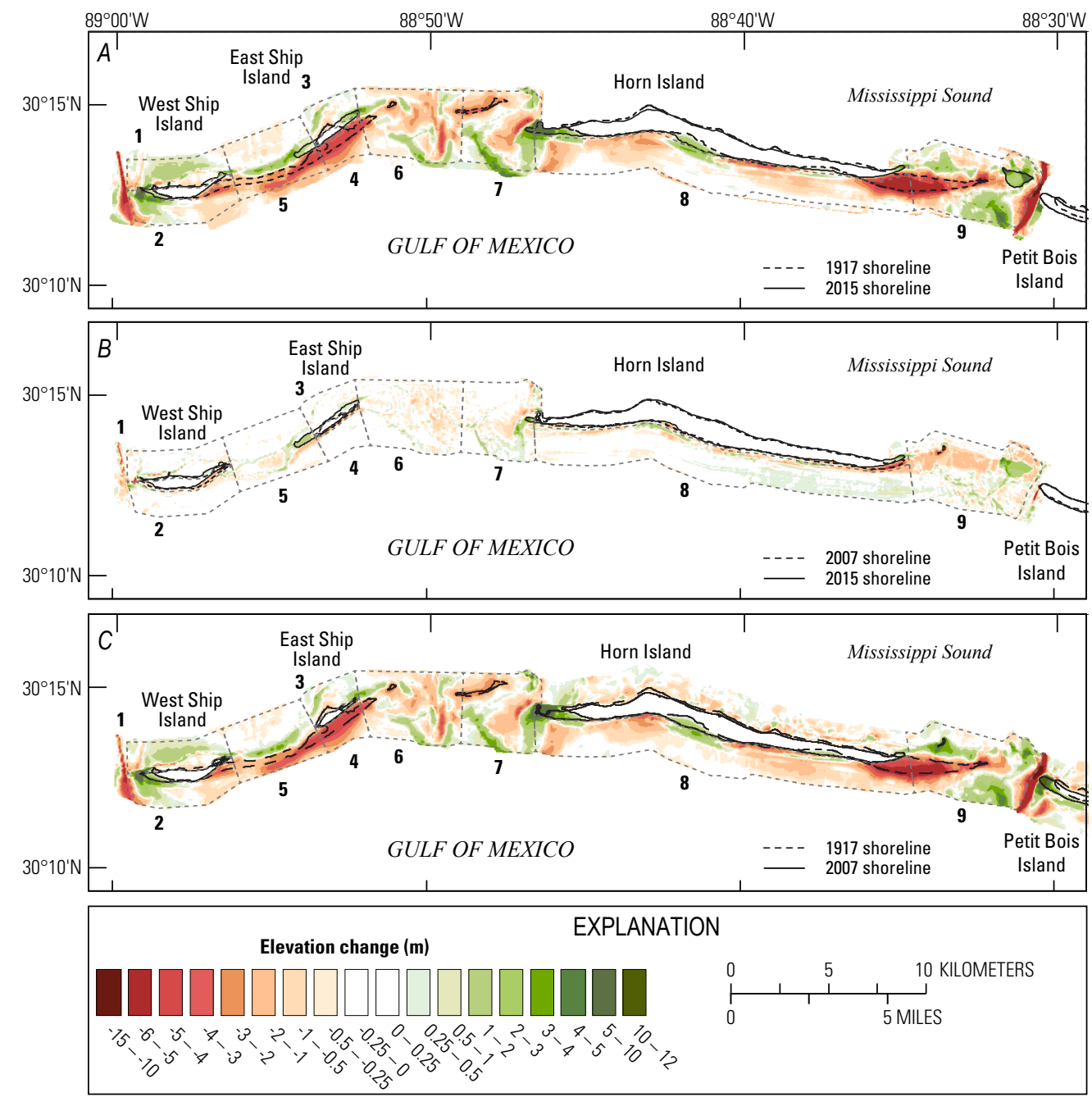

Figure 5. Maps showing elevation change determined by calculating the difference between DEMs for $(A)$ an approximate 96-year period from 1917 to 1920 to 2016; $(B)$ an approximate 7-year period from 2009 to 2016; and (C) an approximate 89-year period from 1920 to 2009. The elevation change represents accretion (positive values) and erosion (negative values) across the time periods. Elevation differences within \pm 0.25 meter $(\mathrm{m})$ are considered "no change." Overlain onto the isopach maps are polygons (labeled 1-9) that represent reference subsections from which volume-change statistics were calculated (table 2) for key morphologic subsections. The isopach grids are available in Buster and others (2017).

which subsequently developed into a spoil island (fig. 3C). Byrnes and others (2012) suggest that this development confined the pass and led to a deepening of the channel through increased tidal flow rates. West of the engineered areas, Horn Island Pass lengthened westward over the study period as the eastern tip of Horn Island eroded.

The gulf shoreface of Horn Island has the highest elevation gradient within the study area. Elevation gradients from the shoreline to $12 \mathrm{~m}$ of water depth (about 1.6-km offshore) average $-4.6 \mathrm{~m} / \mathrm{km}$. Shoreface gradients decrease to the west due to late Holocene prodelta deposits from the St. Bernard delta complex onlapping up to the barrier island platform (Twichell and others, 2011). The western tip of Horn Island is actively migrating west, through lateral spit accretion, into Dog Keys Pass (Morton, 2007, 2008). This migration pushes the natural tidal inlet westward into the 
substantial ebb-tidal delta deposits that occupy the pass (fig. 3). A time-series comparison of the inlet over the past century shows that the westward migration of Horn Island is reducing the surface area of the pass (Buster and Morton, 2011) and increasing tidal velocities, which then incise the inlet deeper into the platform. A second, smaller inlet (Little Dog Keys Pass) also occupies the pass between Horn Island and East Ship Island (fig. 3). Both inlets incise large ebb-tidal delta deposits that extend up to 2-km seaward from the central axis of the platform.

East and West Ship Island are rotated $45^{\circ}$ southwest with respect to Horn Island and have undergone extensive landward lateral migration and land loss over the past century (Morton, 2007, 2008). Over the same time period, the islands were connected but then breached by storms on several occasions (Otvos and Carter, 2013). The breach, known as Camille Cut, widened significantly during the passage of Hurricane Katrina in 2005 (fig. 2). The breach remains shallow, and no significant ebb-tidal deltas have developed while the breach has been open. On both sides of the cut, vestiges of the former island, or possible historic tidal-delta deposits, exist as sandy lobes extending from both islands into Mississippi Sound (fig. 3). Similar to Horn Island, the western spit of West Ship Island is accreting westward into the actively maintained shipping channel adjacent to the island (Twichell and others, 2011).

Measuring temporal changes to the seafloor elevation reveal portions of the seafloor that can be clearly defined as areas of significant positive and negative elevation gain, as well as areas of relative stability (fig. 5). These areas, in general, correspond to the prominent morphologic features of the island platform. The tidal inlets are dynamic and developed large ebb-tidal deltas, whereas the gulf- and sound-side island-shoreface change is constrained, generally, to the immediate shoreline. Westward island migration and island breaching from storms are also reflected in the change analysis. The following section reviews elevation change with respect to the previously defined reference subsections: (1) West Ship Island to Mississippi Sound; (2) West Ship Island to Gulf of Mexico; (3) East Ship Island to Mississippi Sound; (4) East Ship Island to Gulf of Mexico; (5) Camille Cut; (6) Little Dog Keys Pass; (7) Dog Keys Pass; (8) Horn Island to Gulf of Mexico, and (9) Horn Island Pass (see fig. 5 for locations).

\section{Long-term Change (1920-2016)}

Over the past century, the seafloor on the Mississippi Sound side of West Ship Island (fig. $5 A$, location 1) gained sediment $\left(+3.51 \times 10^{6} \mathrm{~m}^{3}\right)$, whereas the gulf side (fig. $5 \mathrm{~A}$, location 2 ) experienced net erosion over the same time period $\left(-0.35 \times 10^{6} \mathrm{~m}^{3}\right)$ (table 2$)$. While accretion on the sound side was relatively uniform throughout the reference subsection, the contemporaneous volume change in the gulf-side subsection reflects the natural migration aspect of erosional updrift and depositional downdrift processes, resulting in a nearly net-zero budget.

Similar to West Ship Island, the reference subsection on the sound side of East Ship Island had a net sediment gain over the long-term (fig. $5 \mathrm{~A}$, location 3 ). The gulf side experienced a more significant degree of erosion $\left(-11.1 \times 10^{6} \mathrm{~m}^{3}\right)$ than its West Ship counterpart; this was the secondlargest amount of loss per unit area within the study (table 2). Comparing erosion on the gulf side of East Ship Island between the 1920-2016 and 1920-2009 time periods (table 2), it is evident that most of the loss occurred before 2009 and is likely the result of punctuated erosion from storms and the resultant land loss of the island (as in fig. 2). For East Ship Island, 10 times as much sediment was lost from the gulf side than was gained on the sound side. This observation indicates, although sediment from the gulf side was likely transported into the sound during overwash events, that much more sediment was lost from the subsection and then transported either westward or offshore. 
Table 2. Accretion and erosion volumes, net change, and rate of change for the reference subsections that represent key morphologic features. Subsections are referenced by their geographic location and are shown as numbered polygons in figure 7. [ $\mathrm{m}^{3}$, cubic meters; $\mathrm{m}^{3} / \mathrm{yr}$, cubic meters per year; MS, Mississippi Sound; GOM: Gulf of Mexico]

\begin{tabular}{|c|c|c|c|c|c|c|c|c|}
\hline $\begin{array}{c}\text { Time } \\
\text { period }\end{array}$ & $\begin{array}{c}\text { Tnterval } \\
\text { in } \\
\text { years }\end{array}$ & Feature & $\begin{array}{c}\text { Accretion } \\
\left(10^{6} \mathrm{~m}^{3}\right)\end{array}$ & $\begin{array}{l}\text { Erosion } \\
\left(10^{6} \mathrm{~m}^{3}\right)\end{array}$ & $\begin{array}{l}\text { Change } \\
\left(10^{6} \mathrm{~m}^{3}\right)\end{array}$ & $\begin{array}{c}\text { Change } \\
\text { per } \\
\text { unit area } \\
\left(\mathrm{m}^{3} / \mathrm{m}^{2}\right)\end{array}$ & $\begin{array}{c}\text { Rate of } \\
\text { change } \\
\left(10^{4} \mathrm{~m}^{3 /}\right. \\
\mathrm{yr})\end{array}$ & $\begin{array}{c}\text { Change } \\
\text { error } \\
\left(+/-10^{5} \mathrm{~m}^{3}\right)\end{array}$ \\
\hline \multirow{9}{*}{$\begin{array}{l}1920 \\
\text { To } \\
2016\end{array}$} & \multirow[t]{9}{*}{96} & West Ship Is. MS (1) & 4.92 & 1.41 & 3.51 & 0.45 & 3.66 & 0.48 \\
\hline & & West Ship Is. GOM (2) & 4.19 & 4.54 & -0.35 & -0.05 & -0.37 & 0.09 \\
\hline & & East Ship Is. MS (3) & 1.78 & 0.56 & 1.22 & 0.28 & 1.27 & 0.41 \\
\hline & & East Ship Is. GOM (4) & 0.01 & 11.08 & -11.08 & -3.01 & -11.54 & 0.13 \\
\hline & & Camille Cut (5) & 3.66 & 12.00 & -8.34 & -0.62 & -8.69 & 1.63 \\
\hline & & Little Dog Keys Pass (6) & 4.82 & 12.70 & -7.88 & -0.43 & -8.21 & 1.52 \\
\hline & & Dog Keys Pass (7) & 9.07 & 9.88 & -0.81 & -0.05 & -0.84 & 0.06 \\
\hline & & Horn Is. GOM (8) & 5.30 & 27.79 & -22.49 & -0.67 & -23.43 & 4.16 \\
\hline & & Horn Is. Pass (9) & 14.81 & 21.80 & -6.98 & -0.32 & -7.27 & 0.45 \\
\hline \multirow{9}{*}{$\begin{array}{l}1920 \\
\text { To } \\
2009\end{array}$} & \multirow[t]{9}{*}{89} & West Ship Is. MS (1) & 4.48 & 1.46 & 3.02 & 0.39 & 3.39 & 0.33 \\
\hline & & West Ship Is. GOM (2) & 4.35 & 4.16 & 0.19 & 0.03 & 0.22 & 0.08 \\
\hline & & East Ship Is. MS (3) & 1.57 & 0.55 & 1.02 & 0.24 & 1.15 & 0.59 \\
\hline & & East Ship Is. GOM (4) & 0.01 & 10.72 & -10.71 & -2.91 & -12.03 & 0.08 \\
\hline & & Camille Cut (5) & 2.92 & 10.80 & -7.88 & -0.58 & -8.85 & 1.76 \\
\hline & & Little Dog Keys Pass (6) & 5.08 & 10.45 & -5.37 & -0.29 & -6.03 & 1.15 \\
\hline & & Dog Keys Pass (7) & 7.96 & 8.87 & -0.91 & -0.06 & -1.03 & 0.23 \\
\hline & & Horn Is. GOM (8) & 5.52 & 28.25 & -22.73 & -0.67 & -25.54 & 3.90 \\
\hline & & Horn Is. Pass (9) & 15.17 & 20.01 & -4.85 & -0.23 & -5.44 & 0.05 \\
\hline \multirow{9}{*}{$\begin{array}{l}2009 \\
\text { To } \\
2016\end{array}$} & \multirow[t]{9}{*}{7} & West Ship Is. MS (1) & 0.85 & 0.50 & 0.35 & 0.04 & 5.02 & 1.26 \\
\hline & & West Ship Is. GOM (2) & 0.44 & 0.74 & -0.30 & -0.04 & -4.27 & 2.17 \\
\hline & & East Ship Is. MS (3) & 0.44 & 0.16 & 0.27 & 0.06 & 3.88 & 0.83 \\
\hline & & East Ship Is. GOM (4) & 0.03 & 0.42 & -0.39 & -0.11 & -5.54 & 0.17 \\
\hline & & Camille Cut (5) & 1.36 & 1.17 & 0.19 & 0.01 & 2.70 & 6.05 \\
\hline & & Little Dog Keys Pass (6) & 0.72 & 2.44 & -1.72 & -0.09 & -24.57 & 7.65 \\
\hline & & Dog Keys Pass (7) & 2.37 & 1.72 & 0.66 & 0.04 & 9.39 & 5.14 \\
\hline & & Horn Is. GOM (8) & 4.49 & 4.11 & 0.39 & 0.01 & 5.55 & 1.11 \\
\hline & & Horn Is. Pass (9) & 5.08 & 7.12 & -2.04 & -0.09 & -29.11 & 0.26 \\
\hline
\end{tabular}


While the loss of a large part of the island is apparent, the volume estimates may reflect sparse data coverage from the earlier time period (fig. 4A), which may result in an underestimation of the sediment contribution.

The Camille Cut reference subsection (fig. 5A, location 5) included the contiguous Ship Island prior to the four breaching events that have occurred since 1947, the most extensive of which happened during Hurricane Katrina (fig. 2). The breaching led to sediment rollover, evident by the accretion behind the former island (fig. $5 \mathrm{~A}$ ). Despite preservation of the sediment volume through rollover within the subsection, this area has a net long-term loss of sediment $\left(-8.3 \times 10^{6} \mathrm{~m}^{3}\right)$, the highest loss of any inlet, as it includes subaerial portions of Ship Island that have been eroded and removed from this subsection. Most of the elevations within this area are within the zone of uncertainty $( \pm 0.25 \mathrm{~m})$, resulting in a high error estimate relative to the volume calculations (table 2 ).

Reference subsections 6 and 7 (fig. 5A, locations 6 and 7) correspond to the Little Dog Keys Pass and Dog Keys Pass tidal inlets, respectively (fig. 3C). These inlets support substantial ebbtidal deltas, and figure $5 \mathrm{~A}$ shows that the deltas have accreted seaward over the long term. However, sediment loss through deflation of the delta cores and incision of the tidal inlets themselves resulted in a net loss from these subsections (table 2). Despite the similar size of the two subsections, the net volume loss for Little Dog Keys Pass is nine times higher than neighboring Dog Keys Pass. In part, this difference was caused by the latter receiving sediment through the lateral spit accretion of Horn Island (reducing net loss).

Patterns of morphologic change across the gulf side of Horn Island (fig. 5A, location 8) reflect the westward migration of the island, as sediments erode from the east end of the island and accrete to the west end. The east side of the Horn Island reference subsection (fig. $5 \mathrm{~A}$, location 8 ) experienced the highest net loss of sediment volume per unit area (table 2). The massive loss of volume and the erosion-accretion patterns shown in figure $5 \mathrm{~A}$ suggest that sediment transport along the island shoreface is not at equilibrium and that in addition to sediment being transported downdrift, sediment was also lost offshore or through overwash. Similar to the volume-change estimates from East Ship Island, the net erosion values may be higher than calculated as a large portion of the island has eroded.

Reference subsection 9 (fig. 5A, location 9) encompasses present-day Horn Island Pass, west of the Pascagoula Ship Channel. Like the tidal inlets to the west, Horn Island Pass has a welldeveloped ebb-tidal delta, which is accreting seaward (figs. 3 and 5), although without the distinctive bypassing morphology evident in Dog Keys Pass and Little Dog Keys Pass. Accretion volumes include a spoil island created by the side placement of sand dredged from the Pascagoula Ship Channel (fig. 3). Despite large areas of accretion, the reference subsection has experienced a net volume loss over the long term, due in large part to the erosion of the formerly subaerial east end of Horn Island (fig. 5A).

\section{Recent Change (2009-2016)}

Differences in sedimentation patterns between the long-term period (1920-2016) and the recent period (2009-2016) reflect a dominance of specific processes over short time intervals. Across the much shorter 7-year time period, the northern Gulf of Mexico experienced few tropical storms, and the bathymetric-change map indicates little change within the reference subsections (fig. 5B). However, erosion rates change dramatically in some areas. The sound side of East and West Ship islands continued to experience net accretion at higher rates (table 2). The rate of erosion increased on the gulf side of West Ship Island, while East Ship Island, although still losing volume, appears to 
have experienced slowed erosion during the recent fair-weather period. The Camille Cut subsection shifted from significant net erosion before 2009 to stable or slight accretion; the potential error in volume estimation is very high.

In contrast, erosion rates in Little Dog Keys Pass tripled since the preceding time period. Dog Keys Pass is the opposite, shifting from slightly negative $\left(-0.8^{3} \times 10^{4} \mathrm{~m}^{3} / \mathrm{yr}\right)$ to experiencing the highest accretion rate within the study area $\left(+9.4 \times 10^{4} \mathrm{~m}^{3} / \mathrm{yr}\right)$. The ebb-tidal deltas associated with both passes continue their seaward growth (fig. $5 B$ ). Since 2009, the reference subsection on the gulf side of Horn Island (fig. $5 B$, location 8 ) has shifted from the highest rate of erosion of any subsection $\left(-25.5 \times 10^{4} \mathrm{~m}^{3} / \mathrm{yr}\right)$ to net deposition $\left(+5.5 \times 10^{4} \mathrm{~m}^{3} / \mathrm{yr}\right)$, in large part due to stabilization of the eastern end of Horn Island (fig. 5). Erosion within the Horn Island Pass reference subsection (fig. 5B, location 9) increased substantially, displaying not only the highest rate of erosion of any subsection over any time period $\left(-29.1 \times 10^{4} \mathrm{~m}^{3} / \mathrm{yr}\right)$, but also the highest magnitude of change between the two time periods (table 2).

\section{Elevation Profiles}

Nine transect $(\mathrm{T})$ lines were selected to directly compare elevation changes across the 1920 , 2009, and 2016 time periods (fig. 3). Transects T1 and T2 are shore parallel on the gulf and sound sides of East and West Ship islands, respectively, and T3 is shore perpendicular through Camille Cut. Transect T4 passes longitudinally through Little Dog Keys and Dog Keys passes, and T5 and T6 pass perpendicularly through the inlets. Transect T7 runs along the gulf shoreface of Horn Island. Transects T8 and T9 run longitudinal and perpendicular through Horn Island Pass, respectively. Specific locations described in the following discussion are annotated along the transects in figure 6 (locations A-E), figure 7 (locations $\mathrm{F}-\mathrm{K}$ ), and figure 8 (locations L-R).

Transect T1 (fig. 6A) extends from the Gulfport Ship Channel east to the edge of the Little Dog Keys Pass Inlet (fig. 3). Westward accretion of the Ship Island Spit from the 1920s position and relocation of the ship channel are evident (location A), and a 2-3 m elevation loss between the 1920 and recent (2009 and 2016) profiles show a breaching of Ship Island at Camille Cut and the subsequent erosion of the East Ship Island shoreface (location B). Transect T2 (fig. 6B), on the sound side of West and East Ship islands (fig. 3), shows the relocated ship channel and elevation gain due to the terminal spit accretion of West Ship (location C). Other than potential elevation loss since the 1920s, the similarity across the profiles indicate that elevations along the sound side of the islands have changed little over the time periods studied in this report. Transect T3 (fig. 6C), which extends from the sound through Camille Cut (fig. 3), shows the results of the breaching of Ship Island between the 1920s and recent surveys (location D). A total of $2 \mathrm{~m}$ of elevation eroded from the cut, and the platform migrated north through rollover processes (location $\mathrm{E}$ ).

Transect T4 (fig. 7A), which extends west to east across Little Dog Keys and Dog Keys passes (fig. 3), captures the rollover of the eastern end of East Ship Island (location F) and the deflation of Little Dog Keys Pass's ebb-tidal delta (location G). At the eastern end of the transect, the western migration and deepening of Dog Keys Pass due to the spit accretion of Horn Island is shown as location H. Transect T5 (fig 7B), which extends north to south across Little Dog Keys Pass and the ebb-tidal delta (fig. 3), shows the deflation of the delta as well as a widening of the inlet since the 1920s (locations I and J). Transect T6 (fig. 7C), which extends across Dog Keys Pass (fig. 3), shows the deepening of the inlet between 1920 and 2009 as the inlet migrated across the transect location in response to the lateral spit accretion of Horn Island westward, as well as the seaward expansion of the tidal deposits at the end of the transect (location K). 



Figure 6. Stacked elevation profiles $(\mathrm{T} 1-\mathrm{T} 3, A-C)$ from the three time periods along the gulf (T1) and sound (T2) sides of West Ship and East Ship islands, and through Camille Cut (T3). See figure 3 for transect locations. Vertical exaggeration (v.e.) is shown. 

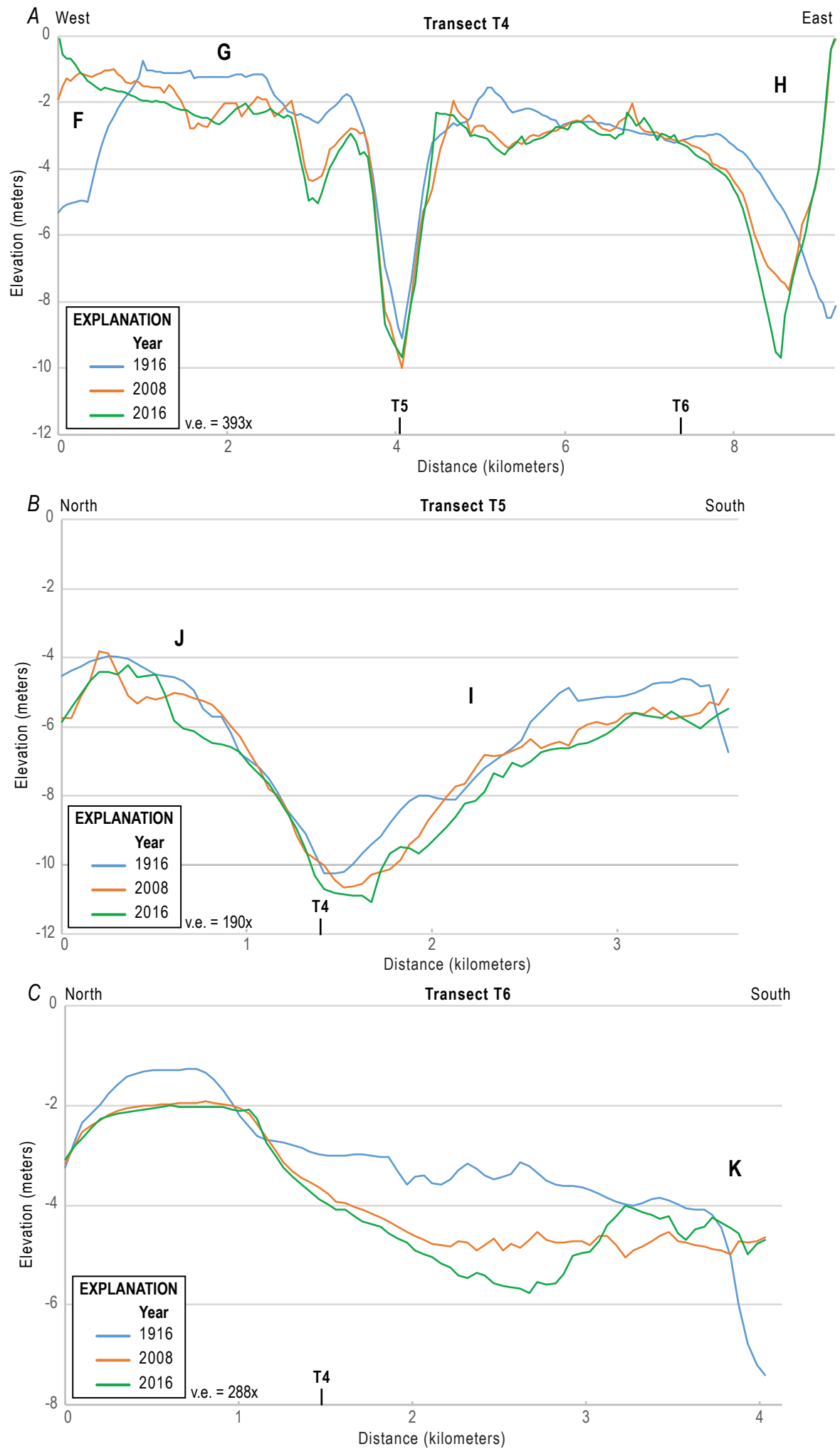

Figure 7. Stacked elevation profiles (T4-T6, A-C) from the three time periods longitudinally across Little Dog Keys and Dog Keys passes (T4), Little Dog Keys Inlet (T5), and Dog Keys Pass (T6). See figure 3 for transect locations. Vertical exaggeration (v.e.) is shown. 

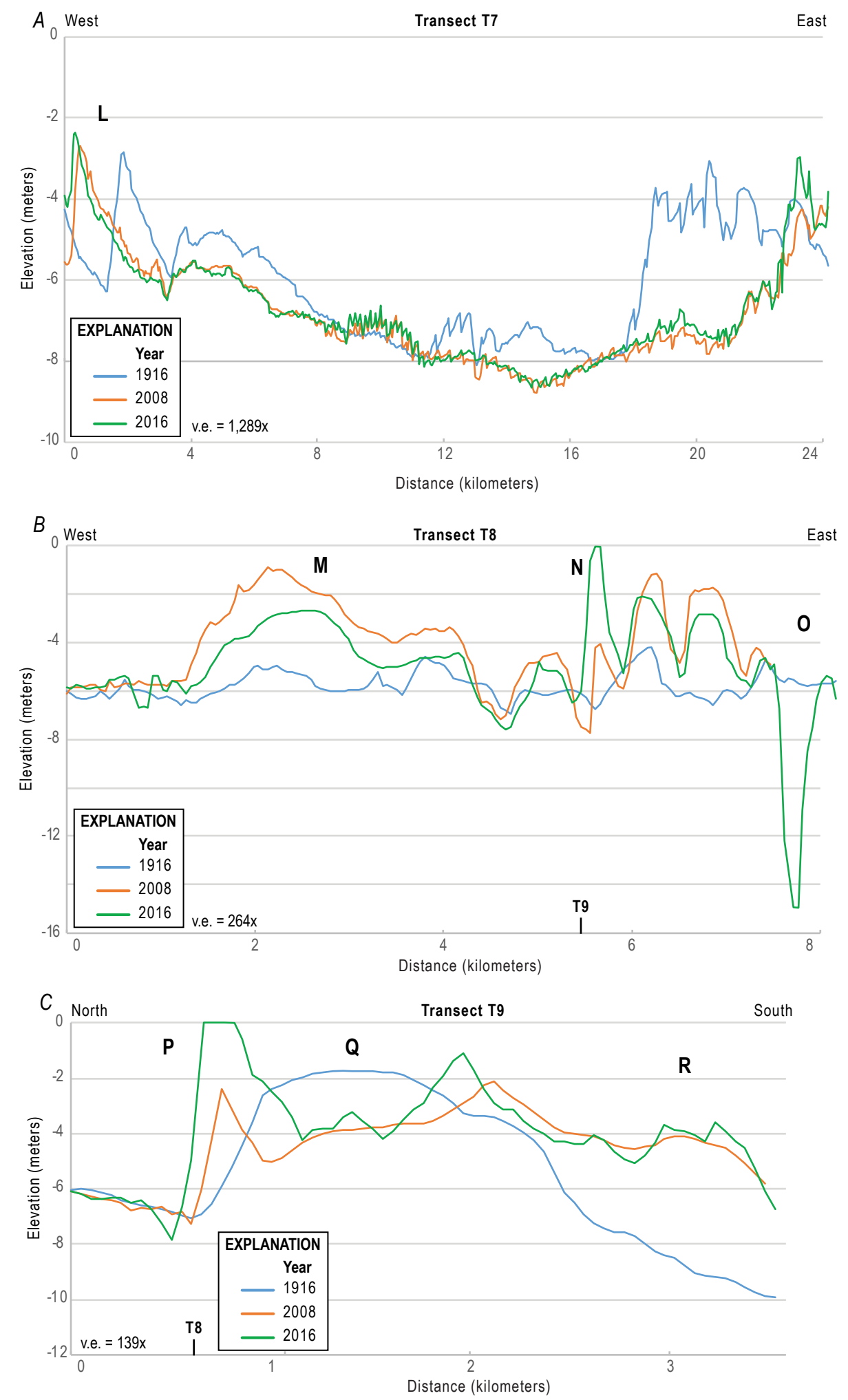

Figure 8. Stacked elevation profiles $(\mathrm{T} 7-\mathrm{T} 9, A-C)$ from the three time periods along Horn Island (T7), longitudinally across Horn Island Pass (T8), and onshore-offshore through the Horn Island Pass (T9). See figure 3 for transect locations. Vertical exaggeration (v.e.) is shown. 
Transect T7 (fig. 8A) extends the length of the gulf side of Horn Island (fig. 3) and shows elevation loss occurred along the transect since the 1920 time period, especially at the eastern end, in response to the erosion of Horn Island. The recent profiles are nearly identical, showing minimal changes in this area, except for the infilling of Horn Island Pass due to westward migration since 2008 and the adjacent westward-migrating high (location L), which is related to Horn Island migration through lateral spit accretion.

Transect T8 (fig. 8B), crosses Horn Island Pass east to west (fig. 3) and shows the dynamic nature of tidal inlet processes, through accretion and subsequent deflation, since the 1920s (location M). The proximity of the transect to the recently developed spoil island (fig. $3 C$ ) is shown by the increase in elevation at location N. At the eastern end of the transect, the deepening of the Pascagoula Ship Channel that has occurred since the 1920s is evident (location O).

Transect T9 (fig. 8C), extending onshore-offshore across Horn Island Pass (fig. 3), also shows the development of the spoil island (location P) and a 2-m deflation of the inlet core (location Q), indicating that a complete restructuring of the pass took place as Horn Island migrated westward. The southward expansion of the ebb-tidal delta is shown by the $2-4 \mathrm{~m}$ of accretion measured at the southern end of the transect (location R; see also fig. 3); the recent periods appear to have been stable at this location.

\section{Temporal and Spatial Sedimentation Patterns}

Over the time periods studied in this report, storms affecting the GUIS varied in frequency, with noticeable morphologic responses during stormy intervals (fig. 2). Between 1920 and 2009, 13 hurricanes (table 1) disrupted long-term sedimentation patterns at the shoreline and shallow shoreface around the islands, especially in the terminal spits and tidal inlet areas (Morton, 2007 and 2008; Otvos and Carter, 2008). Since Hurricane Katrina in 2005, only two tropical storms affected the islands (table 1). Thus, during the 2009-2016 time interval, the island platform can be considered in both a state of recovery from Katrina and a period of little to no storm activity.

Across the island platform, the tidal inlets and island shorefaces respond to storm and nonstorm intervals through changes in sediment accretion and erosion. For example, Flocks and others (2017) demonstrate that neighboring Petit Bois Pass, at the eastern end of the GUIS, experienced a net sediment gain within its ebb-tidal delta during a period of frequent storm activity and a net sediment loss during an interval of infrequent storm activity. Within the study area, a comparison of net volumetric change and the rates of change, over a long time period (1920-2009) and a recent time period (2009-2016), provides insight into change over not only long and short time periods, but also into island platform recovery during the post-Katrina period and inlet response to oceanographic conditions during nonstorm intervals. (fig. 9). These comparisons reveal more than the net change in volume per reference subsection; they also provide evidence for sediment exchange between neighboring subsections.

Volume-change measurements (table 2) are the net difference between accretion and erosion in each subsection. However, to observe the relative magnitude of change across all of the reference subsections, the net volume change for each reference subsection is divided by its area to provide a normalized comparison (fig. $9 A$ ). The rate of change shown in figure $9 B$ is the net volumetric change across each time period (in rate of change per year as cubic meters per year).

Analyses of shoreline change (Morton, 2008) show that of all the islands within GUIS, West Ship Island - especially the sound side - experienced the least lateral migration and retreat. This stability is demonstrated by the consistent, positive sedimentation rates on the sound side of 

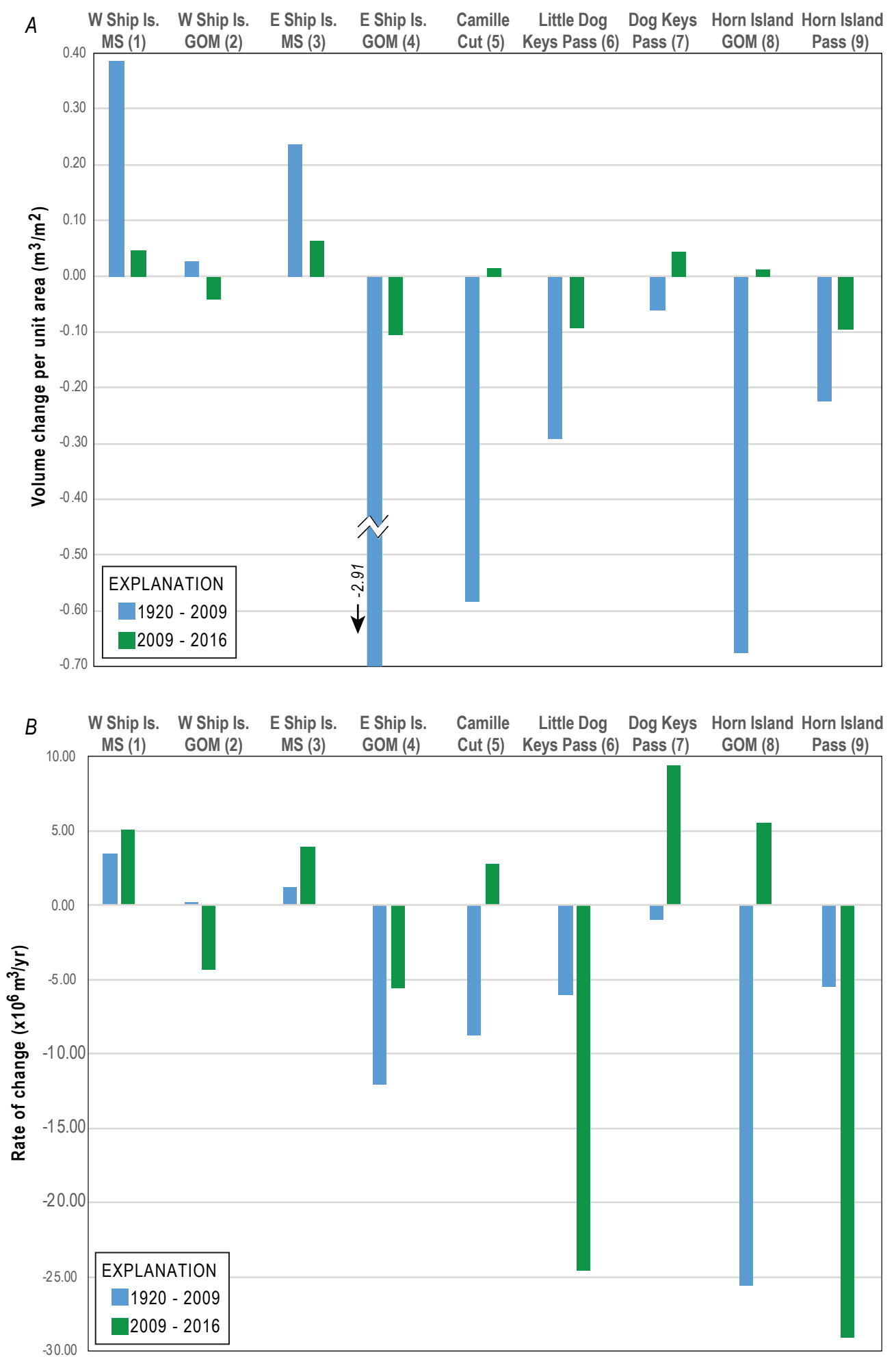

Figure 9. Bar graph showing $(A)$ sediment volumetric change per unit area of each reference subsection (each numbered and shown in figure 5) for the long (1920-2009) and short or recent (2009-2016) time periods; and (B), rate of change for each reference subsection during the same time periods. [GOM, Gulf of Mexico; $\mathrm{m}^{3} / \mathrm{m}^{2}$, cubic meters per square meter; $\mathrm{m}^{3} / \mathrm{yr}$, cubic meters per year; MS, Mississippi.] 
West Ship Island (fig. 9B). Over the long-term, the sound side of West Ship Island (1) had the highest net accretion volumes per unit area within the study (fig. 9A). The gulf side of West Ship Island (2) is relatively stable as well, although it recently shifted from slightly accreting to slightly eroding. Like West Ship Island, the sound side of East Ship Island (3) is experiencing net accretion over both the long and short time periods and is second to West Ship Island in net volume increase per unit area (fig. 9A). The gulf side of East Ship Island is entirely different. For its area, this reference subsection (4) experienced, by far, the most extensive loss of sediment as the island retreats (fig. $9 A$ ) and has the second-highest rate of loss (fig. 9B).

Similarly, Camille Cut (5) has lost a large volume of sediment relative to its size, although it has gained slightly in volume since Hurricane Katrina. Unlike Camille Cut, Little Dog Keys Pass (6) experienced a high rate of erosion since Katrina (fig. 9B): quadruple the long-term rate. Dog Keys Pass (7) is the opposite, with a slight net erosion over the long term but the highest rate of accretion over the short time period since Katrina. As with the shoreface of East Ship Island, the gulf side of Horn Island (8) had a substantial amount of sediment erosion over the long term; the secondhighest volumetric loss per area. In contrast to East Ship Island, which lost sediment during the recent time period, the Horn Island subsection accumulated sediment at a high rate (fig. 9B). Most of this net accretion occurred in the southeast quadrant of the reference subsection (fig. $5 B$ ). Neighboring Horn Island Pass likely provided sediment to Horn Island during the recent time period, as it lost sediment at the highest rate of any reference subsection during this time.

\section{Conclusion}

The morphodynamic effects across the shallow barrier-island platform of Gulf Islands National Seashore are temporally and spatially variable. Within the study area, the tidal inlets Horn Island Pass, Dog Keys Pass, Little Dog Keys Pass, and Camille Cut, and the shoreface of Horn, East Ship, and West Ship islands, act as sediment sources or sinks in response to seasonal oceanographic conditions and storms. From 1920 to 2009, GUIS experienced 27 storms, of which 13 are considered significant (table 1), whereas from 2009 to 2016 there were no significant storm impacts. Thus, the recent time period (2009-2016) experienced an oceanographic environment with less episodic disruptions, and sedimentation patterns could reflect recovery conditions from the direct impact of Hurricane Katrina in 2005.

In response to the lateral migration of the islands, the Horn Island Pass and Dog Keys Pass tidal channels within the inlets are migrating westward, and their associated ebb-tidal deltas are expanding seaward. The shallow breach of Camille Cut has no distinct channel coupled with it and is not comparable to the processes occurring within the established tidal inlets. Over the study period, East Ship Island experienced a dramatic loss of area (Buster and Morton, 2011), and much of the shoreface sediment has been transported west or deposited into the sound and Camille Cut. This migration of sediment into Camille Cut might explain how the breach closed after significant storms (see Morton [2007] and Otvos and Carter [2008] for breach history). However, due to the evolution of East Ship Island to near-shoal conditions, less sediment is available for littoral transport, which may explain why the breach has not closed since Hurricane Katrina. Since this study, the breach has been closed as part of the USACE MsCIP project.

A comparison of shoreface elevations seaward of Horn Island; between the historical (1920) and recent (2009 and 2016) datasets; shows the westward migration of sediment and island accretion at the west end of Horn Island. Temporally, along the gulf side of Horn Island, high rates of net 
erosion over the long-term differ by a slight accretion amount during the most recent, shortest time period and could represent current recovery conditions during a nonstorm interval. This change in sedimentation patterns suggests that sediment erosion of the shoreface occurs during storms, with some of the sediment being transported downdrift, where it contributes to both the spit accretion of the island and the expansion of the ebb-tidal delta. Morton (2008) questions a causal relation between storm activity and land loss, although his analysis shows an increase in island area postKatrina (2005-2007) for all of the islands (fig. 7 in Morton, 2008). The recent (2009-2016) rate of erosion within Horn Island Pass is the highest of any reference subsection over any time period.

Flocks and others (2015) note that in the neighboring Petit Bois Island ebb-tidal delta, sediment is sequestered during stormy intervals and released during nonstormy intervals. The sedimentation pattern within the Horn Island Pass ebb-tidal delta may also reflect this model, as there has been no storm activity during the recent time period. This study could not determine what influence maintenance dredging of the Pascagoula Ship Channel and the development of the spoil island within the inlet have on the morphodynamics of the inlet. Sediment budget estimates by Byrnes and others (2015) indicate that most of the sediment placed at the spoil island has remained, and this sediment is not contributing significant amounts to the pass. This observation is supported by the continued loss of elevation downdrift of the spoil island.

Over time, to varied degrees, all of the Mississippi Barrier Islands experienced a loss in area (Morton, 2008). Relative sea-level rise, diminished sand supply, and mechanical dredging of the tidal inlets produced a net loss of sediment from the system. Across the submerged island platform, sediment is being eroded from the island shoreface and transported westward, where it appends as spit deposits at the western end of the islands or is sequestered along the seaward terminus of the ebb-tidal deltas (fig. 5). Sediment transport from the gulf to sound side of the island occurs but is minimal compared with the net westward littoral transport, as shown by little to no elevation change on the sound side of Ship Island over the study period.

During the recent 7-year time period, West and East Ship islands show what is nearly a mass balance of erosion from the gulf side to accretion on the sound side, as evidenced by the bilateral expansion of subaerial shoreline between 2009 and 2016 on East Ship Island. This island growth is the opposite of the long-term trend of massive land loss. Also, Camille Cut would maintain net erosion values if not for East Ship Island accreting into the reference subsection used to evaluate volume change. These morphological and depositional patterns could reflect short-term, fair-weather, island-platform equilibration processes happening in response to the recent impact of Hurricane Katrina that are obscured across long-term trends in island evolution. 


\section{References Cited}

Buster, N.A., Brenner, O.T., and Flocks, J.G., 2017, Historical and recent coastal bathymetry data nearshore Ship, Horn, and Petit Bois islands, Mississippi: U.S. Geological Survey data release, accessed March 8, 2018, at https://doi.org/10.5066/F7028QFV.

Buster, N.A., and Morton, R.A., 2011, Historical bathymetry and bathymetric change in the Mississippi-Alabama coastal region, 1847-2009: U.S. Geological Survey Scientific Investigations Map 3154, 13 p. [Also available at https://doi.org/10.3133/sim3154.]

Byrnes, M.R., Rosati, J.D., Griffee, S.F., and Berlinghoff, J.L., 2012, Littoral sediment budget for the Mississippi Sound barrier islands, [Mississippi Coastal Improvements Program (MsCIP)]: U.S. Army Corps of Engineers ERDC/CHL TR-12-9 report, 172 p. [Also available at https://www.sam.usace.army.mil/Portals/46/docs/program_management/mscip/docs/ Appendix\%20B\%20-\%20Littoral\%20Sediment\%20Budget\%20Report.pdf.]

Byrnes, M.R., Rosati, J.D., Griffee, S.F., and Berlinghoff, J.L., 2013, Historical sediment transport pathways and quantities for determining an operational sediment budget-Mississippi Sound barrier islands: Journal of Coastal Research, v. 63, p. 166-183. [Also available at https://doi. org/10.2112/si63-014.1.]

DeWitt, N.T., Flocks, J.G., Pendleton, E.A., Hansen, M.E., Reynolds, B.J., Kelso, K.W., Wiese, D.S., Worley, C.R., 2012, Archive of single beam and swath bathymetry data collected nearshore of the Gulf Islands National Seashore, Mississippi, from West Ship Island, Mississippi, to Dauphin Island, Alabama: Methods and data report for USGS Cruises 08CCT01 and 08CCT02, July 2008, and 09CCT03 and 09CCT04, June 2009: U.S. Geological Survey Data Series 675, accessed March 8, 2018, at https://pubs.usgs.gov/ds/675/.

DeWitt, N.T., Stalk, C.A., Fredericks, J.J., Flocks, J.G., Kelso, K.W., Farmer, A.S., Tuten, T.M., and Buster, N.A., 2018, Nearshore coastal bathymetry data collected in 2016 from West Ship Island to Horn Island, Gulf Islands National Seashore, Mississippi: U.S. Geological Survey Data Series 1081, accessed March 8, 2018, at https://doi.org/10.3133/ds1081.

Flocks, J.G., DeWitt, N.T., and Stalk, C.A., 2017, Analysis of seafloor change around Dauphin Island, Alabama, 1987-2015 (ver. 1.1): U.S. Geological Survey Open-File Report 2017-1112, 19 p., accessed March 8, 2018, at https://doi.org/10.3133/ofr20171112.

Flocks, J.G., Ferina, N.F., and Kindinger, J.L., 2011, Recent geologic framework and geomorphology of the Mississippi-Alabama shelf, northern Gulf of Mexico, in Buster, N.A., and Holmes, C.W., eds., Gulf of Mexico origin, waters, and biota-Volume 3-Geology: College Station, Texas, Texas A\&M University Press, p. 157-173.

Flocks, J.G., Kindinger, J.L., and Kelso, K.W., 2015, Geologic control on the evolution of the inner shelf morphology offshore of the Mississippi barrier islands, northern Gulf of Mexico, USA: Continental Shelf Research, v. 101, June, p. 59-70. [Also available at https://doi.org/10.1016/j. csr.2015.04.008.]

Fritz, H.M., Blount, C., Sokoloski, R., Singleton, J., Fuggle, A., McAdoo, B.G., Moore, A., Grass, C., and Tate, B., 2007, Hurricane Katrina storm surge distribution and field observations on the Mississippi barrier islands: Estuarine, Coastal and Shelf Science, v. 74, no. 1-2, p. 12-20. [Also available at https://doi.org/10.1016/j.ecss.2007.03.015.]

Guy, K.K., 2015a, Shorelines extracted from Landsat imagery-Horn Island, Mississippi: U.S. Geological Survey data release, accessed March 8, 2018, at https://doi.org/10.5066/F7XW4GVG. 
Guy, K.K., 2015b, Shorelines extracted from Landsat imagery-Ship Island, Mississippi: U.S. Geological Survey data release, accessed March 8, 2018, at https://doi.org/10.5066/F7DZ06CD.

Miselis, J.L., Buster, N.A., and Kindinger, J.L., 2014, Refining the link between the Holocene development of the Mississippi River Delta and the geologic evolution of Cat Island, MS-Implications for delta-associated barrier islands: Marine Geology, v. 344, September, p. 274-290. [Also available at https://doi.org/10.1016/j.margeo.2014.05.021.]

Morton, R.A., 2007, Historical changes in the Mississippi-Alabama barrier islands and the roles of extreme storms, sea level, and human activities: U.S. Geological Survey Open-File Report 2007-1161, 44 p. [Also available at https://doi.org/10.3133/ofr20071161.]

Morton, R.A., 2008, Historical changes in the Mississippi-Alabama barrier-island chain and the roles of extreme storms, sea level, and human activities: Journal of Coastal Research, v. 24, no. 6, p. 1587-1600. [Also available at https://doi.org/10.2112/07-0953.1.]

National Oceanic and Atmospheric Administration, 2018a, National Data Buoy Center archives: National Data Buoy Center website, accessed December 12, 2018 https://www.ndbc.noaa.gov/.

National Oceanic and Atmospheric Administration, 2018b, Hurricane Flossy-September 24, 1956 web page: National Weather Service website, accessed December 12, 2018, at https://www. weather.gov/mob/flossy.

Otvos, E.G., 1981, Barrier island formation through nearshore aggradation-Stratigraphic and field evidence: Marine Geology v. 43, p. 195-243.

Otvos, E.G., and Carter, G.A., 2008, Hurricane degradation-Barrier development cycles, northeastern Gulf of Mexico-Landform evolution and island chain history: Journal of Coastal Research v. 24, no. 2, p. 463-478. [Also available at https://doi.org/10.2112/06-0820.1.]

Otvos, E.G., and Carter, G.A., 2013, Regressive and transgressive barrier islands on the north-central Gulf Coast-Contrasts in evolution, sediment delivery, and island vulnerability: Geomorphology, v. 198, September, p. 1-19. [Also available at https://doi.org/10.1016/ j.geomorph.2013.05.015.]

Otvos, E.G., Giardino, M.J., 2004, Interlinked barrier chain and delta lobe development, northern Gulf of Mexico: Sedimentary Geology v. 169, no. 1-2, p. 47-73. [Also available at https://doi. org/10.1016/j.sedgeo.2004.04.008.]

Southern Climate Impacts Planning Program, 2018, Global peak surge map web page: SURGEDAT - The world's storm surge data center website, accessed December 12, 2018, at http://surge. srcc.lsu.edu/data.html\#GOM_DB.

Twichell, D., Pendleton, E., Baldwin, W., Foster, D., Flocks, J., Kelso, K., DeWitt, N., Pfeiffer, W., Forde, A., Krick, J., and Baehr, J., 2011, The shallow stratigraphy and sand resources offshore of the Mississippi barrier islands (ver. 1.1): U. S. Geological Survey Open-File Report 2011-1173, 63 p., accessed March 8, 2018 at https://doi.org/10.3133/ofr20111173.

Weber, K.M., List, J.H., and Morgan, K.L., 2005, An operational mean high water datum for determination of shoreline position from topographic lidar data: U.S. Geological Survey OpenFile Report 2005-1027, accessed December 12, 2018, at https://pubs.usgs.gov/of/2005/1027/. 




